\title{
PAX8 Gene Rearrangement Negative
}

National Cancer Institute

\section{Source}

National Cancer Institute. PAX8 Gene Rearrangement Negative. NCI Thesaurus. Code C160481.

A genetic finding indicating that rearrangement of the PAX8 gene has not been detected in a sample. 